\title{
AEROMAGNETIC MAP OF THE BRADSHAW MOUNTAINS AND VICINITY, YAVAPAI COUNTY, ARIZONA
}

\author{
GEOPHYSICAL INVESTIGATIONS \\ MAP GP-758
}

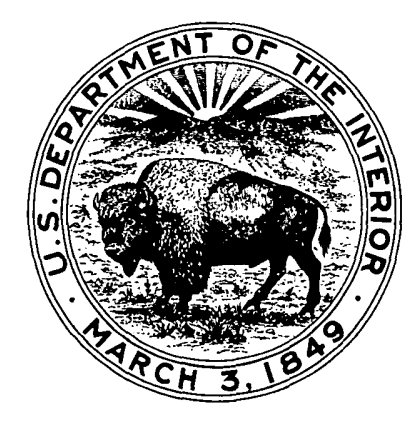

